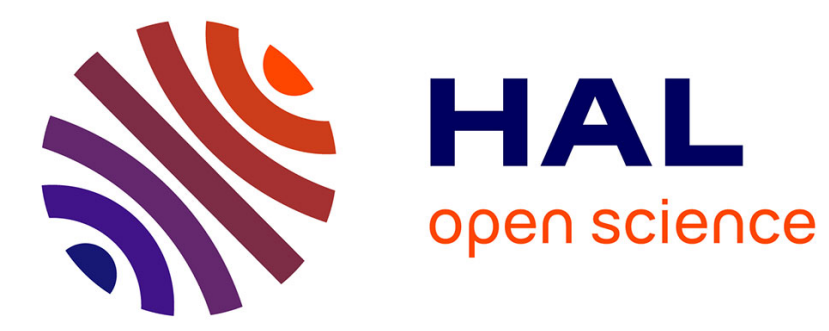

\title{
Ghost texts in Alice Munro's stories
}

Corinne Florence Bigot

\section{To cite this version:}

Corinne Florence Bigot. Ghost texts in Alice Munro's stories. Short Fiction in Theory \& Practice, 2017, 7, pp.141 - 152. 10.1386/fict.7.2.141_1. hal-02994823

\section{HAL Id: hal-02994823 \\ https://hal.science/hal-02994823}

Submitted on 21 Dec 2020

HAL is a multi-disciplinary open access archive for the deposit and dissemination of scientific research documents, whether they are published or not. The documents may come from teaching and research institutions in France or abroad, or from public or private research centers.
L'archive ouverte pluridisciplinaire HAL, est destinée au dépôt et à la diffusion de documents scientifiques de niveau recherche, publiés ou non, émanant des établissements d'enseignement et de recherche français ou étrangers, des laboratoires publics ou privés. 


\title{
Ghost texts in Alice Munro's Short Stories
}

\author{
Corinne Bigot Université Toulouse Jean Jaurès, France \\ published in Short Fiction in Theory \& Practice \\ Volume 7 Number 2 pp 141-142, 2017
}

The British short story writer Sarah Hall suggests a natural connection between the short story and haunting. The greatest short stories, she explains, 'reverberate magnificently, beyond their own limits; they haunt, humour, sometimes vex and occasionally enlighten' (Hall 2013: n.pag.). She also underlines the role readers have to play: 'there are no solvent, tonic or consoling endings. The reader is left to decide what everything might mean [...] Some might want such a reading experience infrequently, some every day, many never' (Hall 2013: n.pag.). The Canadian short story writer Alice Munro herself suggests that haunting is what she is looking for when she tells Eleanor Wachtel 'I want the stories to keep going on, I want the story to exist somewhere so that in a way it's still happening or happening over and over again' (Wachtel 1991: 293).

How does Munro achieve this haunting effect? As a Munro reader, I am often troubled by a story that 'reverberates', as Sarah Hall puts it, in my mind; and as a Munro reader I often feel that another story 'hovers as a subtext', as Judith Miller puts it (Miller 2002: 53), when I read a new story. And the memory of this other story increases the troubling sense of haunting the stories provoke.

For there is no denying that a sense of déjà vu pervades her stories or that Munro tends to delve into the same material, over and over again. In this essay I will argue that far from being a fault, Munro's exploration of familiar material is part of her aesthetics and explains the sense of haunting her stories provoke. To do so, I will use the filter of Michel Charles's concept of the 'ghost text', which he developed in the larger context of reader theory.

In Introduction à l'étude des textes(1995) Michel Charles claims that every literary text is surrounded by other possible texts, which he calls 'ghost scenarios' or 'ghost texts' because they remain hidden. They 'lay behind the surface of the written text' (Charles 1995: 168, my translation), like the 'lining' of the text (Charles 1995: 176) and haunt the text, as if the text was a 'double' text (Charles 1995: 168). Charles argues that the ghost text is both absent - the author had several scenarios in mind but did not pursue them (1995: 168) - and present as these alternative scenarios left 'traces' on the page (1995: 176). The ghost text is produced by the reader and 'only exists in the reader's imagination' (1995: 176). Charles therefore suggests we call the reader's response - imagining the ghost scenario - 'the reader's erratic reading' (1995: 208), which might be erroneous as it deviates from what is written on the page. I believe Michel

Charles's concepts of ghost scenario and erratic reading to be relevant to the kind of stories Alice Munro writes. As Munro delves into the same material, the sense of déjà vu that pervades the stories we read translates into the feeling that another story hovers as a subtext, and influences our understanding of the new story. Munro's stories are haunted by ghost texts that inform our reading, as we fill in the gaps and silences in her stories, and imagine alternative scenarios as impressions give way to assumptions and deductions, based on similarities. As my reading of 'Gravel' will show, this is particularly relevant in stories offering partial accounts of deaths or accidents.

In his Introduction à l'étude des textes(1995) Michel Charles contends that any written text is 'surrounded by other possible texts, alternative scenarios the text could have followed but which the writer abandoned along the way' (Charles 1995: 168). Charles suggests we call these other texts 'ghost scenarios' or 'ghost texts' as they are somewhat invisible - they lurk behind the surface - and he sees the final text as 'doubled by these other texts' (1995: 166) since he sees the ghost text as a 'lining' (1995: 177). Charles also argues that the final text somehow still contains traces of these other, hidden, texts, which haunt the text we read (1995: 176). The concept of the ghost text enables him to take into account disturbing elements in a text, to see them in a more positive light, instead of being seen and dismissed as 'anomalies' in a text (1995: 176) and to claim that they should be included and considered 'crucial elements that readers and critics base their interpretation on' (Charles 1995: 176). 
The scenarios lining the text may have been abandoned by the writer but have left 'traces', which the reader sees or feels, Charles argues, which influences her reading. Following up on Charles's ideas, Francine Cicurel has suggested that dashes which pepper a text could be likened to stitches, and also to entryways into these alternative scenarios (Cicurel 2002: 61). Cicurel's idea works well with Munro's texts, which are often peppered with dashes (Bigot 2014: 193-94), but I would like to consider another recurring

stylistic device that features predominantly in Munro's stories: the use of modal auxiliaries that destabilize meaning and open up other possible scenarios, as demonstrated by Ajay Heble's seminal work on Munro's 'paradigmatic discourse' or 'discourse of absence' (Heble 1994: 5). Munro's language, Heble argues, implies the other 'possibilities' that could have filled the same slot in a given sequence (Heble 1994: 5). Munro is interested in what might have happened, just as much as what happened. This is one way to understand what a ghost scenario is. For instance in 'Accident', the main protagonist, Frances, looks back at her life and cannot help thinking that her life would have been different if her lover's son had not died: 'if he hadn't gone out in the snow that day [...] Frances would not live in Ottawa now, she would not have her two children' (Munro [1982] 1995: 109). At the end of 'What is Remembered', a much later story, the narrator also evokes the possibility that the character might have had another life (she might not have stayed with her husband after she cheated on him) but as the narrator points out, this is not about regrets, but about possibilities, as these other lives are seen as scenarios to be mused about, if not explored in one's mind: 'there was another sort of life she could have had - which was not to say she would have preferred it [...] she could think of that other life simply as a kind of research' (Munro 2001: 242). With Munro, we are always reminded that the narrator and the writer could have written another story.

It should come as no surprise therefore that Munro often goes back to the same root scenario, only to ursue another direction, which was left behind in a previous story.

While a sense of déjà vu permeates her stories, Munro seems to try out new variations, to experiment with the same material, which she looks at from a different angle. Throughout her 14 collections and 150 stories, Munro has been composing a sequence of never-ending variations on recurring themes, so that her stories seem to be haunted by recurring figures such as the mother who is left behind, women who run away, the child who disappears, and by dead children. For example, 'Nettles', from Munro's 2001 collection, also hinges on the influence a child's death may have on people's lives. In 'Accident', the death of his son is instrumental in the man's decision to leave his wife and marry Frances, his mistress, while 'Nettles' explores the alternative scenario. When the narrator meets her childhood love again, many years after they were separated, she is prevented from confessing her feelings when the man tells her about his younger son's death. As the narrator reflects that accidents like that either 'break [people] apart or bind [them], for life' (Munro 2001: 184), she brings together the two possibilities by the marker 'or' linking two exclusive elements that cannot coexist, but which she has explored elsewhere.

Due to Munro's ability to conjure up visual images, I often remember previous characters or scenes when reading a new story. Thus, the accidental death of the child in 'Nettles' that haunts his father (Munro 2001) brings to mind the little boy's death in 'Accident'. As the accident in 'Nettles' is not described - Mike only says that he ran over his child when he backed out of his driveway - while a detailed account of the accident is given in 'Accident' (Munro [1982] 1995: 91), the earlier story plays an even stronger role, supplying details that are absent in 'Nettles'. While 'Nettles' foregrounds the narrator's enduring love for Mike and her memories of their childhood games, the child's death haunts the story, all the more as it connects to other children's accidents that Munro has written about, creating a web of subtexts that informs the impact of the story.

As a Munro reader, I tend to read a story through the filter of earlier stories, being aware of and sensitive to various kinds of similarities, from plotlines to recurring types of characters and events, to stylistic devices that help alternative scenarios proliferate. This is why I would like to explore Michel Charles's concept further and argue that the concept of ghost scenarios prompting an erratic reading could also include other stories. As a ghost text, a story we remember will influence our reading, all the more so as Munro's stories resist closure and force the reader to fill in the blanks. In what I believe to be a remarkable essay, Judith Miller states that Munro 'writes mystery stories, maybe murder mysteries' (Miller 2002: 43, emphasis added), and describes how she feels compelled to re-read a story she is quite familiar with ('Something I've Been Meaning to Tell You') in order to understand why she is convinced that the main protagonist (Et) murdered her sister (Char) since this is not to be found anywhere in the story. Miller explains she 'cannot help wondering' about this or that detail, as very few clues are offered. In the end, after rereading the story, she is inclined to think that Char was killed by her husband rather than by her sister. Miller's readings could be labelled as 'erratic' since neither of them is supported by any clear-cut evidence in the text. As 
Miller demonstrates, silence plays a prominent role in these stories: 'silences in the conversations [...] resonate with meaning [...]. They resonate with waiting, with lurking danger' (Miller 2002: 44). A Munro reader cannot help wondering about inconclusive clues and cannot help noticing the silences. In 'Something I've Been Meaning to Tell You', as the very title suggests, revelation is forever deferred, and the silences in the conversations are doubled by narrative reticence. Char's death happens in the blank space between two paragraphs, which explains why erratic readings proliferate. As the short story, as a genre, is elliptical by nature, readers usually fill in the gaps, and Munro takes advantage of this propensity, 'linking the omissions in the text to themes of speech and silence in the lives of her characters' (Cox 2015: 58-59). In Munro's stories, the gap between paragraphs becomes the blank space the reader is prompted to fill in. Thus, I cannot help imagining that in 'The Time of Death', where the accident (a 9-year-old child boils water to clean the house, an action that results in her younger brother's death) takes place between two paragraphs, the girl Patricia Parry may have acted out of anger. While many stories by Munro foreground silence, both on the level of the diegesis and of the narrative, another characteristic of her fiction is to offer several versions of the same event, which ultimately emphasizes discrepancies (Bigot 2014). An account can be simultaneously muddled by the proliferation of versions and hollowed out by negations and modality, creating gaps, through which ghost scenarios can surface.

I would like to turn to one of Munro's most recent stories, 'Gravel', as the emblematic ghost story that is both haunted by a dead/undead child and haunted by several ghost texts. A first-person narrative, 'Gravel' opens with a reference to the past and the evocation of the gravel pit in front of the trailer where the narrator, her sister, their mother and the mother's lover lived for a time (Munro 2012: 91). We gradually learn that the narrator has been urged by a grief counsellor and by her partner to give an account of the accident that happened when she was a young child - her sister drowned, in the gravel pit. The narrator presents her account as an attempt to write down the story, in order to heal the wound or 'rout [...] out [her] demons', as her partner puts it (Munro 2012: 106). But the reader suspects the demon cannot be

routed out. Although she starts with a clear and brief assertion - 'A Saturday' (Munro 2012: 100) - the narrator's account soon proves to be quite problematic. While she remembers that Caro spoilt her pleasure at watching a TV show, the title of which she gives, things will be very different when it comes to the scene outside, and the dialogue with her sister that took place before Caro's death. Most noticeable are phrases such as 'I don't know' (Munro 2012: 102); then, the narrator confesses that she cannot remember what she said, or even whether she argued with Caro: 'I believe I still put up some argument [...] Why? I must have said that, or I may have just stood there not obeying and trying to work up another argument' (Munro 2012: 102, emphasis added). The first modal auxiliary, 'must', is weakened by the second one, 'may', rendering the account even less certain. Furthermore, both assertions are linked by the coordinator 'or', which, as pointed out by Blandine Pennec, is a crucial strategic device Munro uses in her previous story 'Child's Play', enabling the narrator to create effects of indeterminacy and vagueness (Pennec 2016: 203-05). Pennec's analysis can be applied to 'Gravel' as in the later story the exclusive interpretation of 'or' only reinforces uncertainty, as it does in 'Child's Play': 'two hypotheses are opposed and they happen to exclude each other [...] but the text does not provide us with elements of answer' (Pennec 2016: 204). Munro uses the coordinator 'or' to create ambiguity and increase confusion, which is also the effect her frequent use of non-harmonic modality creates, as shown by Pilar Somacarrera's analysis of her early stories. 'Contradictory' or 'non-harmonic modality', Somacarrera argues, reinforces the 'pervasive narratorial ambiguity' of a story (Somacarrera 1996: 84).

This clearly holds true of 'Gravel' where the recollection of a putative argument is immediately followed by two accounts of Caro's death, which from the start are shown to be unreliable, and contradictory:

In my mindI can see her picking up Blitzee and tossing her [...] then backing up, Caro backing up to take a run at the water. Running, jumping, all of a sudden hurling herself at the water. But I can't recall the sound of the splashes [...] perhaps I had turned towards the trailer by then - I must have done so.

When I dream of this, I am always running. And in my dreams, I am running not towards the trailer but back towards the gravel pit. I can see Blitzee floundering around and Caro swimming towards her, swimming strongly, on the way to rescue her. (Munro 2012: 102-03, emphasis added) The second account is clearly dismissed as a dream, and the first one starts with 'in my mind', casting doubt as to whether this is what happened. And of course, the first version contains contradictions, and it is riddled with modality ('perhaps', 'I must have'). Stylistic echoes between the two accounts ('In my mind'/ 'in my dreams') and the repetition, 'I can see', all eventually cast doubt as to what she did see. Numerous 'ing' forms abound in both the dream and the first accounts, conveying the impression of a film that she replays in her mind. In 
the end, the difference between the film she imagines ('in my dreams') and the film she replays in her mind is unclear. In other words, there is no knowing what happened.

These accounts are followed by an emphatic structure, reasserting reality (Munro 2012: 103), but the statement is followed by several negations, such as 'I don't know', and by several maybes (Munro 2012: 103), as she tries to remember what she did once she arrived at the trailer. The narrator interrupts the account by recalling what the grief counsellor wanted her to conclude (Munro 2012: 103), which she first denies and then reconsiders: 'it's possible I did knock' (Munro 2012: 104). As Christine Berthin has pointed out, 'the constant seesaw movement of concessive and contrastive forms, of assertions and refutations' can be read as 'the sign of an open wound' (Berthin 2015: 84). The narrator fails to give any clear and reliable account of Caro's death, which means that she does not endorse any version of reality; in other words, her amnesia also puts her in the clear. Eventually, death is 'suspended by the impossibility for the narrator of accepting the fact of death and her involvement in the drama' (Berthin 2015: 84). Ultimately, Caro remains undead (Berthin 2015: 85), forever haunting the gravel pit, which becomes the site of an unclosed wound and a site for the undead child, who proves to be the ghost in the story, to haunt the text, the narrator's memory and the reader's mind.

The incipit of the story and metonymically, its title, draw attention to this site, the gravel pit: 'At that time we were living beside a gravel pit. [...] just a minor pit [...]. In fact the pit was shallow enough to lead you to think that there might have been some other intention for it' (Munro 2012: 91). The insistence on this 'minor' pit is surely not a coincidence in a story that proves to be so full of gaps and inconsistencies. As stories such as 'Gravel' and 'DeepHoles' show, Munro constructs her landscape with specific features such as holes and pits, snow-covered mounds, frozen lakes and blankets of snow. As both Ventura (2002) and Miller (2002) have demonstrated, the silences of these snowscapes are never empty as dead/undead characters haunt these loci, which also signal the gaps in the stories. In this respect, 'Gravel' proves

to be a most interesting instance of a story that is haunted by a dead/undead child, who haunts the gravel pit, and a story that is haunted by other ghosts (children) and other texts.

Gaps and stylistic devices such as contradictory modality and the use of the coordinator 'or' to reinforce ambiguity are means for Munro to introduce doubt and suspicion, and therefore foster alternative scenarios and 'erratic readings'. The feeling that the narrator may feel guilty for having waited too long to call

her mother, or for not talking Caro out of jumping, gives way to even more sinister possibilities - the narrator did more than not call for help, and maybe had a hand in her sister's death. Although sibling rivalry is suggested, and although it is clear that the narrator resented Caro for spoiling her pleasure

at watching her TV show (this is one of the few things she remembers), the reader will not find much evidence supporting her erratic reading. As with the death of Char in 'Something...', there are no certainties, but only an annoyingly persistent suspicion on the reader's part, and the haunting presence of an alternative scenario doubling or lining the text we read.

One of the reasons why the undead child haunts the reader's imagination and helps foster other scenarios is that 'Gravel' is haunted by other ghost texts and other dead/undead children. Children's games that end badly (or could have ended badly) and sibling rivalry are nothing new in Munro's fiction, nor are accidents where children die. 'Gravel' reads as a variation on a plotline to be found in 'Child's Play' (from Munro's 2009 collection), which itself revisited the scenario of an earlier story, 'Monsieur les Deux Chapeaux' ([1985] 1996).

Such similarities force the reader to draw connections between the stories, and the earlier story or stories play the role of ghost texts that in Judith Miller's words 'hover' as subtexts (Miller 2002: 47) and therefore influence our reading.Lynn Blin has suggested we look at a Munro story as a musical score. She notes that an individual story contains elements that seem to be mentioned in passing, but that the reader who stays attuned to these elements will notice 'how they are picked up, expanded on and arranged, just like themes in a musical score' (Blin 2015: 47). Munro, Blin explains, 'sets a tune in our heads, so to speak, and then, through various linguistic devices, enables us to pick it up again and again' (2015: 48). I believe the metaphor of a musical score could be applied to her work, and that we should stay attuned to her tones and undertones, and to her variations and their haunting notes. While a reader's erratic reading (imagining the worst) is hers, it is influenced by similarities that are craftily introduced through narrative and stylistic devices. They are particularly effective when Munro works with affects such as sibling rivalry and jealousy. Thus, recent stories such as 'Gravel' and 'Night' (2012) are pervaded and haunted by elements already present in 'Child's Play', 'Monsieur les Deux Chapeaux' ([1985] 1996) and 'The Time of Death' ([1968] 2000). An accident/murder is avoided in 'Monsieur les Deux Chapeaux' when a hunting rifle is found and its trigger gets pulled during a party where two little boys are left on their own (Munro [1985] 
1996: 76-77). The boy who pulls the trigger happens to be the brother of the boy who is shot at. The narrative in 'Monsieur...' foregrounds the boy's incapacity to remember, and the stylistic similarities with 'Gravel' are striking:

Colin grabbed [the gun] himself, and what happened then he absolutely

did not know, or remember, ever. He didn't remember pointing the gun.

He couldn't have pointed it. He didn't remember pulling the trigger,

because that was what he couldn't have done. He couldn't have pulled

the trigger. He couldn't remember the sound of a shot but only the

knowledge that something had happened - the knowledge you have

when a loud noise wakes you out of sleep.

(Munro [1985] 1996: 76-77)

As in 'Gravel', the narrator intimates that the boundary between what is real and what is unreal is blurred. The concluding paragraph however clearly states that Colin is aware that he has contemplated doing the unthinkable, and that 'his job' for the rest of his life is 'to watch out for something like that happening' (Munro [1985] 1996: 83). Colin, it seems, knows that he wishes his brother were out of his life.

Sibling rivalry is crucial in 'Monsieur...' as it is in 'Gravel', but another factor needs to be taken into account: the boy who is shot at, the brother who is their mother's favourite son, is repeatedly said not to be retarded (Munro [1985] 1996: 57), so 'Monsieur' also hovers as a subtext when I read 'Child's Play' (Munro 2009) where two children end up committing the unthinkable - killing another little girl called Verna, who has Down's syndrome. The brothers in 'Monsieur...' are said to look very much alike and Ross's affection for and dependence on Colin is strongly emphasized. In 'Child's Play', the narrator learns that since Verna used to live in the same house, she was assumed to be her sister (Munro 2009: 199). She is therefore said to 'persecute' the narrator, reminding me of the fact that Colin thinks his brother persecuted a girl at school. In 'Child's Play', Verna's crime is to like the narrator, and to be likened to her, or, maybe, to be like her - not only her shadow but her double. Furthermore, Verna's murder is described as part of a series of games (Bigot 2016: 182), reinforcing the similitude with 'Monsieur...' since the accident

happened during a children's party, where games were being played. Colin fires the gun, and although Ross is not harmed, Colin is haunted by the idea that he could have killed his brother. 'Child's Play' reverses the situation as the narrator evokes the possibility that the murder could have been an accident with modal auxiliaries introducing another scenario: 'This could have been an accident. As if we, in trying to get our balance, grabbed on to this nearby large rubbery object' (Munro 2009: 221, emphases added).

As in 'Gravel', the narratives of 'Child's Play' and 'Monsieur...' are undermined by several references to the narrators' faulty memories, which reads as another familiar theme. For instance in 'Child's Play', the narrator, who claims she does not remember what happened after the murder, is rather vague about

how long it took Verna to die: 'The whole business probably took no more than two minutes. Three? Or a minute and a half?' (Munro 2009: 222). The similarities with 'Gravel' whose narrator does not remember how long she waited on the trailer's step - in other words, how long it took for Caro to drown, and

die - are striking: 'I don't know if I sat there for five minutes? More? Less?' (Munro 2012: 103). In both cases, the child's time of death is occulted. These remarks on time encourage me to see 'The Time of Death' (Munro [1968] 2000), the story about the accidental death of yet another special child, as yet

another ghost text for these later stories - the correspondence between this title and the later stories is striking - that haunts them.

Finally, 'Monsieur...' may also be said to hover as a subtext to 'Night' (Munro 2012) since the child also faces the possibility of committing the unspeakable act, that is to say, killing her sibling. The narrator of 'Night' confesses to having had a very strong urge to strangle her sister, every night for three months, which she could resist only by getting out of bed (Munro 2012: 277). Munro herself in the introduction to the Penguin edition of The Moons of Jupiter suggested that her stories tended to be 'invaded by familiar shapes and voices' (Munro [1985] 1996: xiv). She was writing about the difference between personal stories and 'observed' stories (i.e. less personal stories), but her statement applies to her stories at large, whether they are personal or observed, as they are invaded by familiar, haunting shapes, voices and events.

'Night' is one of the four autobiographical pieces that conclude Dear Life and about which Munro explains that they are 'autobiographical in feeling, though not, sometimes entirely in fact' (Munro 2012: 255). Thus, the sister in 'Night' is called Catherine, not Sheila, as if to further create distance with Munro's real family. Yet the autobiographical piece exposes feelings that have repeatedly haunted and informed Munro's depiction of sibling rivalry throughout her oeuvre. 
In other words, as a Munro reader, I often come to a story through the filter of another, earlier, story, but may also look back at an earlier story through the filter of a later story. In Munro's case, the ghost scenario that haunts her stories may have been explored in an earlier story, and in an uncanny reversal, the later text may get to haunt the earlier text. My re-interpretation of 'The Time of Death' (my suspicion that Patricia may have killed her brother) is influenced by my having read these other stories, which all emphasize sibling rivalry, the death of a sibling, and one death by murder. The pattern that I identify is mine, but it is suggested by the presence of the familiar shapes and voices, as well as stylistic devices that create connections in my mind.

Munro has said she likes looking at her characters' lives 'over a number of years, without continuity, like catching them in snapshots' (Hancock 1987: 200). Picking up Munro's metaphor of the series of snapshots, I think that awareness of previous stories may induce the reader to reorganize the snapshots and provide alternative endings. The plotline in 'Deep-Holes' where a son disappears from his parents' life, reads as a variation of the scenario in 'Silence' (Munro 2004). Both stories suggest the child's need for freedom and foreground the mother's strategies to survive the loss of her child. Furthermore, both stories actually develop a plotline that is suggested as a possible scenario in a much earlier story, 'The Moons of Jupiter', when the narrator learns that one of her daughters 'wanted to be incommunicado for a while' (Munro [1982] 1995: 221). In 'Deep-Holes', the reason for the son's strong desire never to talk to his father again is never explained, nor is it in any way explicitly linked to the slight undercurrent of domestic unhappiness that transpires through the mother's efforts to placate her husband.

In 'Deep-Holes', attention is drawn to the erosion of the rocks (Munro 2009: 94) and also to a sign reading, 'Caution. Deep-holes'(2009: 94, original capitalization). The focalizer, a young wife and mother, wonders, 'Why the hyphen?' (2009: 94). This hyphen may be one of the elements that explicitly encourage the readers to draw connections between stories, connection of one scenario to its ghost scenarios. The role played by the ghost text that hovers as a subtext when one reads a story by Munro in the resulting erratic reading - imagining the worst - is striking with stories where violence explodes or lurks. As Héliane Ventura has pointed out, Munro's stories highlight some type of foundational violence, symbolically wielded, or physically enacted on the body (Ventura 2010: 253). Munro powerfully explores this scenario in 'Fits' in which the peace of a small town is shattered by an inexplicable murder followed by a suicide. The main protagonist, one of their neighbours, tries to figure out what happened although his wife, who discovered the bodies, is rather reticent. As the couple talk about 'fights' and 'fits' of violence, Peg's son suddenly tells his mother that as a child he used to be afraid when his parents fought, to the point that he imagined that they would come at him with a knife (Munro [1985] 1996: 126). Robert tries to reassure his stepson, but his theory that 'fits' can happen sheds a disturbing light on what may happen within a family.

'Fits' is a ghost text that hovers when one reads 'Dimensions' in which the husband kills his three children to punish his wife who has walked out on him during a quarrel (Munro 2009: 15-17). The undercurrent of family violence that explodes in 'Dimensions' is perceptible in 'Runaway' and also transpires in

'Deep-Holes', which depicts a wife's constant efforts to please and placate her husband. Therefore I cannot help reading 'Deep-Holes' through the filter of 'Runaway' and 'Dimensions' where the wives' efforts to placate their authoritative husbands herald disputes that, in 'Runaway', lead to moral violence and in 'Dimensions', to murders.

As I look back at an earlier story through the filter of a later story, I notice both pregnant silences and inconclusive or anomalous details. These elements are, in Michel Charles's reading, traces of the ghost scenario which the writer did not pursue in the story we are reading (Charles 1995: 169), and which she explored elsewhere. My own belief (or erratic reading) that Carla's death looms at the end of 'Runaway' was confirmed after I read 'Dimensions', from the next collection, since the later story describes the explosion of the husband's violence. The explosion of violence in 'Dimension' also reveals or exposes, to pick up the photography metaphor, the possibility of marital violence which is present in 'Fits'. Reading 'Fits', 'Runaway' and 'Dimensions', I perceive an intricate web that connects them and influences my response to the stories, both on the level of each story, and on the level of a pattern that they create. With Munro, intratextuality is a crucial component that helps us read.

There is no denying that in the case of a short story writer who often revisits the same scenarios over the years, the stories may make particular demands on the reader in her engagement with memory practices, demanding a specific way of reading - observing the parts, individual stories, but perceiving the whole, a collection, but also the entire oeuvre. Munro's stories, which make sense on their own as individual stories, may yield other interpretations when read in connection with earlier stories. 
In this article, I have tried to show that Munro's tendency to delve into the same material cannot be ascribed to lack of inspiration and should not be seen as a shortcoming. Rather, this tendency has to be seen as part of her aesthetics as the Canadian short story writer, like a music composer, composes new

variations on recurring themes as a way to experiment with the material from a different angle. Her variations are also instrumental in the haunting effect that she tries to create. Alice Munro writes stories that, when read individually, often contain multiple possibilities that are shown to be other paths that could have been chosen, and may be explored. The reader is therefore encouraged to do so. Her stories, however long they can be, are marked by narrative reticence and resist closure, leaving the reader with the task of not only imagining endings, but also imagining scenarios when reading contradictory accounts of

sudden deaths, or when the narrator's reticence or faulty memory leave room for scenarios to surface in the reader's imagination.

But this is also where our knowledge of other stories plays a crucial part. A ghost text, in Michel Charles's view, cannot be separated from the practice of reading. Its presence results from the effect the text and its details, including anomalies, have on the reader's imagination. I believe my own 'erratic' readings to be influenced by earlier stories. I believe that as she composes a new story, Munro is aware of the role and influence her previous variations may have. Earlier stories play the role of 'ghost texts' as defined by Michel Charles, texts that hover as subtexts and lurk behind the actual story we read. In turn, a more recent story may influence my interpretation of an earlier story, so that the later text may paradoxically also become a ghost text. While Munro's stylistic devices often force the reader to see connections and patterns that encourage her to conjure up a ghost scenario, these stylistic devices also mean that no reader can ever be certain of what happened. The lack of certainty and the proliferation of multiple scenarios are instrumental in creating the haunting qualities of Munro's stories.

\section{REFERENCES}

Berthin, C. (2015), 'Of wounds and cracks: A reading of Dear Life', Commonwealth

Essays and Studies, 37:2, pp. 79-85.

Bigot, C. (2014), Les silences de la nouvelle, Rennes: PUR.

(2015), 'Ghost texts, patterns of entrapment and lines of flight: Reading

stories from Too Much Happinessand Dear Lifein connection with earlier

stories', in M. Buchholtz and E. Sojka (eds), Alice Munro: Reminiscence,

Interpretation, Adaptation and Comparison, Frankfurt: Peter Lang, pp. 59-74.

(2016), 'Jeux et enjeux de la confession d'une meurtrière: "Child's

Play" d'Alice Munro', in E. Jouve, A. Guillain and L. Talairach (eds), L'Acte

inqualifiable, ou le meurtre au féminin (Unspeakable Acts: Murder by Women),

Bruxelles, Bern, Berlin, Frankfurt am Main, New York, Oxford and Wien:

Peter Lang, pp. 181-97.

Ghost texts in Alice Munro's stories

www.intellectbooks.com 151

Blin, L. (2015), 'Sweet dissonance', Commonwealth Essays and Studies, 37:2, pp. 45-55.

Charles, M. (1995), Introduction à l'étude des textes, Paris: Seuil.

Cicurel, F. (2002), 'Le texte et ses ornementations', in J. Authier-Revuz and

M.-C. Lala (eds), Figures d'ajout, Paris: Presses de la Sorbonne Nouvelle,

pp. 51-63.

Cox, A. (2015), 'Looking back with Alice Munro', in C. Bigot and C. Lanone

(eds), With a Roar from Underground, Alice Munro'sDance of the Happy

Shades, Nanterre: Presses Universitaires de Paris Ouest, pp. 55-64.

Hall, S. (2013), 'Why we should have a short story laureate', The Guardian,

11 October, https://www.theguardian.com/books/2013/oct/11/sarah-hallshort-story-laureate. Accessed 8 May 2017.

Heble, A. (1994), The Tumble of Reason, Alice Munro's Discourse of Absence,

Toronto, London and Buffalo: University of Toronto Press.

Howells, C. A. (1998), Alice Munro, Manchester: Manchester University Press.

Miller, J. (2002), 'Deconstructing silence: The mystery of Alice Munro',

Antigonish Review, 129, pp. 43-52.

Munro, A. ([1982] 1995), The Moons of Jupiter, London: Vintage. 
([1985] 1996), The Progress of Love, London: Chatto and Windus.

([1968] 2000), Dance of the Happy Shades, London: Vintage.

(2001), Hateship, Friendship, Courtship, Loveship, Marriage, London:

Chatto \& Windus.

(2004), Runaway, London: Chatto \& Windus.

([1974] 2004), Something I've Been Meaning to Tell You, London: Vintage.

(2009), Too Much Happiness, London: Chatto \& Windus.

(2012), Dear Life, London: Chatto \& Windus.

Pennec, B. (2016), 'Tensions and blurring effects linked to the use of the coordinator OR in "Child's Play" by Alice Munro', in E. Jouve, A. Guillain and

L. Talairach (eds), L'Acte inqualifiable, ou le meurtre au féminin (Unspeakable

Acts: Murder by Women), Bruxelles, Bern, Berlin, Frankfurt am Main, New

York, Oxford and Wien: Peter Lang, pp. 199-209.

Somacarrera, P. (1996) 'Exploring the impenetrability of narrative: A study of

linguistic modality in Alice Munro's fiction', Studies in Canadian Literature,

21:1, pp. 79-91.

Ventura, H. (2002), 'The ordinary as subterfuge: Alice Munro's "Pictures of the

Ice"', Journal of the Short Story in English, 38, pp. 73-85, http://jsse.revues.

org/204. Accessed 11 March 2016.

(2010), 'The relevance of the chimera: Ekphrasis, anamorphosis and

phantasy in "Runaway" by Alice Munro', The Relevance of Theory, Tropismes,

16, pp. 239-60.

Wachtel, E. (1991), 'Interview with Alice Munro', in L. Spalding and M.

Ondaatje (eds), The Brick Reader, Toronto: Coach House, pp. 288-94.

SUGGESTED CITATION

Bigot, C. (2017), 'Ghost texts in Alice Munro's stories', Short Fiction in Theory \&

Practice, 7:2, pp. 141-152, doi: 10.1386/fict.7.2.141_1

CONTRIBUTOR DETAILS

Corinne Bigot is a senior lecturer at Université Toulouse 2 Jean Jaurès,

France. Her main research interests are diasporic short fiction by women and

Corinne Bigot

152 Short Fiction in Theory \& Practice

Canadian literature. She defended a Ph.D. in Canadian literature, on Alice

Munro's short stories, at the Université of Nanterre. Most of her publications are devoted to Alice Munro's work: she has published a dozen essays

on Munro's stories as well as a monograph in French (Alice Munro, les silences

de la nouvelle, Presses Universitaires de Rennes, 2014) and co-authored a

book entitled Sunlight and Shadow, Past and Present(Presses Universitaires de

France, 2014), with Catherine Lanone, devoted to Alice Munro's first collection. She co-edited a volume of essays, With a Roar from Underground. Alice

Munro'sDance of the Happy Shades (Presses Universitaires de Paris Ouest, 2015), and edited a special issue of Commonwealth Essays and Studies, Writing

for Dear Life, devoted to Munro's stories (2015).

Contact: Université Toulouse 2 Jean Jaurès, 5 allées Antonio Machado, 31000

Toulouse, France.

E-mail: Corinne.bigot@wanadoo.fr

Corinne Bigot has asserted her right under the Copyright, Designs and Patents

Act, 1988, to be identified as the author of this work in the format that was

submitted to Intellect Ltd. 